\title{
Effect of immunization of sexually immature pullets against poly- $\alpha$-L-glutamic acid on long-term fertility
}

\author{
D. P. Froman, A. M. Elaghbary and J. D. Kirby \\ Department of Poultry Science, Dryden Hall 208, Oregon State University, Corvallis, \\ OR 97331-3402, USA
}

\begin{abstract}
Summary. Poly- $\alpha$-L-glutamic acid (PGA) is a polypeptide synthesized within the upper oviduct and uterovaginal junction of the hen. Sexually immature pullets were immunized against PGA. These virgin pullets, and immunized and non-immunized controls, were inseminated at 25 weeks of age and then monthly throughout a 30 -week egg production interval. While birds immunized against PGA were free of PGA as evidenced by an absence of immunoprecipitation when rabbit anti-PGA serum was overlayed with oviduct extract, immunization had no effect on long-term fertility and therefore is unlikely to have an immunosuppressive or antigen-masking biological role with respect to spermatozoa. We suggest instead that PGA could act as a calcium binding protein.
\end{abstract}

Keywords: poly- $\alpha$-L-glutamic acid; immunization; fertility; hen

\section{Introduction}

Mukherjee et al. (1983) demonstrated that the antigenicity of rabbit spermatozoa was reduced by two proteins found within prostatic fluid, i.e. uteroglobin and transglutaminase. It was suggested that poly- $\alpha$-L-glutamic acid (PGA), an oviduct protein of unknown biological function, might likewise have an immunosuppressive or antigen-masking action. This hypothesis was based upon the following observations.

First, while fowl spermatozoa are antigenic (for review, see Classen, 1977), insemination as a means of immunization and any subsequent effect on fertility are suspect (for reviews, see Lake, 1969; Classen, 1977). Second, Harrison \& Heald (1966) demonstrated that PGA is localized within the infundibulum and upper magnum of the fowl as well as in the uterovaginal junction. Fertilization occurs within the infundibulum (Olsen \& Neher, 1948; Okamura \& Nishiyama, 1978), and spermatozoa are sequestered within the tubular glands of the uterovaginal junction (Bobr et al., 1964a, b). In addition to being a weak immunogen, PGA has been shown to induce erythrocyte aggregation in a dose-related manner (Maeda \& Shiga, 1985). This observation was intriguing in view of the report of Tingari \& Lake (1973) of apparent sperm agglutination within the lumina of the uterovaginal glands.

Finally, the experimental design of Heald et al. (1967) did not preclude an antigen-masking role for PGA. These researchers proposed that PGA maintained sperm fertilizing ability. They tested their hypothesis by immunizing 9 sexually immature pullets against PGA and then inseminated them after lay had begun. However, only 2 inseminations were performed, and these were only 1 week apart. We reasoned that, if PGA did have an antigen-masking role, such an insemination scheme might only serve to immunize pullets. Furthermore, because fertility of eggs was assessed for only 1 week after each insemination, a latent effect would not have been detected. Therefore, the objective of the present work was to determine whether the long-term fertility of pullets immunized against PGA was affected. 


\section{Materials and Methods}

Poly- $\alpha$-L-glutamic acid (P4886; Sigma Chemical Co., St. Louis, MO, USA) was precipitated with methylated bovine serum albumin (MBSA; A-1009, Sigma) according to the procedure outlined by Plescia et al. (1964). This procedure may be used to increase an immune response to an acidic polymer of weak or unknown antigenicity. At 9 weeks of age, 54 Single Comb White Leghorn (SCWL) pullets were assigned randomly to 1 of 3 treatments: (1) immunization against PGA complexed with MBSA, (2) immunization against MBSA, or (3) no immunization. Each bird immunized against PGA received $250 \mu \mathrm{g}$ PGA from each of 3 weekly injections. A comparable amount of MBSA was also given to these birds as well as to those used as immunized controls. Freund's Complete Adjuvant (F-5881, Sigma) was used for initial immunizations and Freund's Incomplete Adjuvant (F-5506) thereafter.

At 18 weeks of age pullets were transferred from a floor pen into individual cages within a single bank. Cage assignments were made randomly. Pullets were photostimulated with $14 \mathrm{~h}$ of light daily, and a daily record of lay was initiated per pullet. Each immunized pullet received a single booster injection at 22 weeks of age.

At 25 weeks of age, each pullet was inseminated intravaginally with $1.0 \times 10^{8}$ spermatozoa procured from the pooled ejaculates of $25 \mathrm{SCWL}$ roosters. Egg collection commenced on the 2 nd day after insemination and continued for $2 \mathrm{l}$ days. Upon the 4th day of incubation, eggs were broken open to examine their contents for embryonic development. Subsequent inseminations were made at monthly intervals.

Fertility was determined similarly following insemination at 29 and 55 weeks of age. Percentages of fertilized eggs from each treatment were plotted by day. Because plots conformed to logistic functions, parameters of $y(x)=$ $\gamma / 1+\mathrm{e}^{\beta(x-x)}$ were estimated by iterative least squares (Freund \& Littell, 1986). Fertility over the 21 -day intervals after inseminations at 25, 29 and 55 weeks of age was compared among treatment groups with the Mantel-Haentzel statistic, which affords a robust evaluation of binary data (Mantel \& Haentzel, 1959).

At 61 weeks of age, birds were weighed and then killed by cervical dislocation. The majority of birds were killed 20-30 min after oviposition. Each oviduct was dissected free of the body cavity and straightened by severance of associated ligaments. The first $15 \mathrm{~cm}$ of each oviduct, which included the infundibulum and upper magnum, was cut free and frozen on solid $\mathrm{CO}_{2}$. Oviduct samples were stored at $-20^{\circ} \mathrm{C}$ before extraction. Extracts were prepared and the presence of PGA determined by immunoprecipitation with rabbit anti-PGA serum (Harrison \& Heald, 1966). The 61-week body weights and cumulative egg production were analysed by single classification analysis of variance (Sokal \& Rohlf, 1969).

\section{Results and Discussion}

Immunization of sexually immature pullets against PGA had no effect $(P>0.05)$ on 61 -week body weight or cumulative egg production (Table 1). Analysis of data by iterative least squares provided estimates of initial fertility, $\gamma$, and the time at which a half-maximal response occurred, $\tau$, for each treatment group following the first, second and final inseminations (Table 2). While $\tau$ values varied among trials, they were comparable among treatment groups within any given trial.

Table 1. Final body weight and cumulative eggs laid per pullet from non-immunized control birds and birds immunized against either poly- $\alpha$-L-glutamic acid (PGA) complexed to methylated bovine serum albumin (MBSA) or

MBSA alone

\begin{tabular}{lccc}
\hline Treatment & $\begin{array}{c}\text { No. of } \\
\text { pullets }\end{array}$ & $\begin{array}{c}\text { Body weight } \\
(\mathbf{k g})\end{array}$ & $\begin{array}{c}\text { Cumulative } \\
\text { eggs } \\
\text { per pullet }\end{array}$ \\
\hline Control & 18 & $2 \cdot 07 \pm 0.045$ & $217 \pm 4 \cdot 1$ \\
PGA + MBSA & 18 & $2 \cdot 09 \pm 0.038$ & $217 \pm 4 \cdot 0$ \\
MBSA & 18 & $2 \cdot 12 \pm 0.040$ & $217 \pm 4 \cdot 0$ \\
\hline
\end{tabular}

Values are mean \pm s.e.m.

When overall fertility was compared among treatment groups following any given insemination (Mantel \& Haentzel, 1959), the probability of fertility being equivalent among treatment groups was $>0.99$ (Table 2 ). This confirmed the results of our preliminary analysis (Elaghbary \& Froman, 
Table 2. Initial percentages of fertility, time of half-maximal fertility, and overall fertility within 21-day egg collection intervals following insemination of pullets previously immunized against poly- $\alpha$-L-glutamic acid (PGA) complexed to methylated bovine serum albumin (MBSA), MBSA alone, or non-immunized control pullets

\begin{tabular}{|c|c|c|c|c|c|}
\hline Insemination* & $\begin{array}{c}\text { Pullet } \\
\text { age } \\
\text { (weeks) }\end{array}$ & $\begin{array}{l}\text { Antigen } \\
\text { treatment }\end{array}$ & $\begin{array}{l}\text { Initial } \\
\text { fertility } \\
(\%)^{\dagger}\end{array}$ & $\begin{array}{l}\text { Half-maximal } \\
\text { fertility (days) } \ddagger\end{array}$ & $\begin{array}{l}\text { Overall } \\
\text { fertility } \\
(\%) \S\end{array}$ \\
\hline I & 25 & $\begin{array}{l}\text { PGA + MBSA } \\
\text { MBSA } \\
\text { None }\end{array}$ & $\begin{array}{l}95 \cdot 2 \\
95 \cdot 8 \\
92 \cdot 6\end{array}$ & $\begin{array}{l}13 \cdot 9 \\
13 \cdot 2 \\
13 \cdot 5\end{array}$ & $\begin{array}{l}57 \pm 2 \cdot 4 \\
54 \pm 3 \cdot 7 \\
55 \pm 3 \cdot 4\end{array}$ \\
\hline 2 & 29 & $\begin{array}{l}\text { PGA + MBSA } \\
\text { MBSA } \\
\text { None }\end{array}$ & $\begin{array}{l}100 \cdot 0 \\
100 \cdot 0 \\
100 \cdot 0\end{array}$ & $\begin{array}{l}11.6 \\
11.3 \\
11.4\end{array}$ & $\begin{array}{l}57 \pm 2 \cdot 9 \\
57 \pm 2 \cdot 2 \\
55 \pm 4 \cdot 4\end{array}$ \\
\hline 8 & 55 & $\begin{array}{l}\text { PGA + MBSA } \\
\text { MBSA } \\
\text { None }\end{array}$ & $\begin{array}{l}98 \cdot 4 \\
99 \cdot 4 \\
99 \cdot 0\end{array}$ & $\begin{array}{l}12 \cdot 9 \\
13 \cdot 1 \\
13 \cdot 3\end{array}$ & $\begin{array}{l}57 \pm 3 \cdot 1 \\
59 \pm 2 \cdot 3 \\
60 \pm 3 \cdot 4\end{array}$ \\
\hline
\end{tabular}

*A total of 8 inseminations were made at monthly intervals. Each of 18 hens per treatment was inseminated with $1 \times 10^{8}$ spermatozoa per insemination.

$\dagger$ Defined as the estimate of $\gamma$, an asymptotic value, which is a parameter of the logistic function $y(x)=\gamma / 1+\mathrm{e}^{\beta / \tau-\mathrm{x})}$.

‡Defined as the estimate of $\tau$, which is a parameter of the logistic function $y(x)=\gamma / 1+\mathrm{e}^{\beta\langle\tau-x)}$.

$\S$ Each value is given as mean \pm s.e.m. Based upon statistical analysis with the Mantel-Haentzel statistic, the probability of fertility being equivalent among treatment groups following any given insemination was $>0.99$.

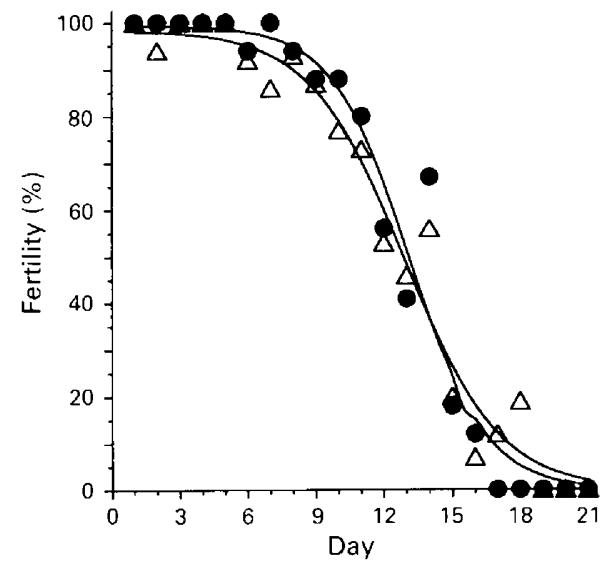

Fig. 1. Duration of fertility after insemination of pullets at 55 weeks of age, which had been immunized at 9 weeks of age against poly- $\alpha$-L-glutamic acid (PGA) complexed to methylated bovine serum albumin (MBSA; $\triangle$ ) or against MBSA alone $(\bullet)$. Solid lines represent the functions $y(x)=98.4 / 1+\mathrm{e}^{-0.4807(12 \cdot 9-x)}$ and $y(x)=99 \cdot 4 / 1+\mathrm{e}^{-0.5958(13 \cdot 1-x)}$ for duration of fertility of immunized and immunized control pullets, respectively. Unlike oviduct extracts from pullets immunized against MBSA alone, PGA was not detected in similar extracts from pullets immunized against PGA complexed with MBSA. Poly- $\alpha$-L-glutamic acid was detected via immunoprecipitation with rabbit anti-PGS-serum.

1988). The similarity in duration of fertility between pullets immunized against PGA and immunized controls after repeated inseminations over $>30$ weeks of production is shown in Fig. 1. Neither initial fertility nor time of half-maximal fertility were affected. Therefore, immunization 


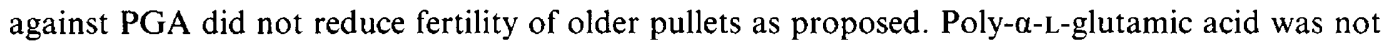
detected in oviduct extracts from pullets immunized against PGA at 9 weeks of age, whereas immunoprecipitation demonstrated the presence of PGA in oviduct extracts from immunized control and control pullets alike.

These results have confirmed that PGA is indeed a member of the array of proteins synthesized by the hen's oviduct. They also corroborate the conclusion of Heald et al. (1967) that PGA is not essential for maintenance of sperm fertilizing ability following insemination. Nevertheless, it cannot be concluded that PGA has no relationship to spermatozoa. Sperm interaction with PGA would depend upon secretion of PGA by oviduct epithelial or glandular cells, and this has yet to be demonstrated.

In conclusion, we suggest that PGA, providing it is secreted into the lumen of the oviduct, could act as a calcium-binding protein. According to Williams (1970), $\mathrm{Ca}^{2+}$ preferentially forms complexes with oxygen donor ligands such as the carbonyl group of the peptide bond and carboxylate groups. At physiolopgical $\mathrm{pH}$, the carboxyl groups of Glu residues are ionized, as the $\mathrm{pK}_{\mathrm{a}}$ of these groups is $4 \cdot 6$ (Creighton, 1983). In the case of PGA, such an interaction has been confirmed in vitro by Dirscherl \& Dohr (1974). Therefore, the adsorption of $\mathrm{Ca}^{2+}$ to PGA in the presence of spermatozoa within the uterovaginal glands and infundibulum might prevent premature sperm activation and help block polyspermy, respectively. Such a role for PGA is attractive in view of the involvement of $\mathrm{Ca}^{2+}$ in fowl sperm motility (Ashizawa \& Wishart, 1987; Wishart \& Ashizawa, 1987), the requirement of an influx of extracellular $\mathrm{Ca}^{2+}$ for induction of the acrosome reaction (Wassarman, 1987), and the failure of spermatozoa entrapped within the extravitelline layer to undergo an acrosome reaction (Okamura \& Nishiyama, 1978). Therefore, the biological role of PGA might best be inferred from immunohistochemical studies of the oviduct in conjunction with in-vitro experimentation with spermatozoa.

\section{Paper No. 8879 of Oregon Agricultural Experiment Station.}

\section{References}

Ashizawa, K. \& Wishart, G.J. (1987) Resolution of the sperm motility-stimulating principle of fowl seminal plasma into $\mathrm{Ca}^{2+}$ and an unidentified low molecular weight factor. J. Reprod. Fert. 81, 495-499.

Bobr, L.W., Lorenz, F.W. \& Ogasawara, F.X. (1964a) Distribution of spermatozoa in the oviduct and fertility in domestic birds. I. Residence sites of spermatozoa in fowl oviducts. J. Reprod. Fert. 8, 3947.

Bobr, L.W., Ogasawara, F.X. \& Lorenz, F.W. (1964b) Distribution of spermatozoa in the oviduct and fertility in domestic birds. II. Transport of spermatozoa in the oviduct. J. Reprod. Fert. 8, 49-58.

Classen, H.L. (1977) Antigenicity of spermatozoa and its relationship to fertility in domestic fowl. Ph.D. dissertation, pp. 61-74. University of Massachusetts.

Creighton, T.E. (1983) Chemical nature of polypeptides. In Proteins: Structures and Molecular Properties, pp. 2-60. W. H. Freeman, New York.

Dirscherl, W. \& Dohr, H. (1974) Binding of calcium ions by amino acids and peptides, especially by poly- $\alpha-\mathrm{L}-$ glutamate. Hoppe-Selyers $Z$ Physiol. Chem. 355, 1135-1138.

Elaghbary, A.M. \& Froman, D.P. (1988) A reexamination of the role of poly- $\alpha$-L-glutamic acid on duration of fertility in the chicken. Poultry Sci. 67 (Suppl. 1), 82, abstr.
Freund, R.J. \& Littell, R.C. (1986) Observations. In $S A S$ System for Regression, pp. 47-74. SAS Institute Inc., Cary, NC.

Harrison, D.G. \& Heald, P.J. (1966) The Isolation of poly- $\alpha$-L-glutamic acid from the oviduct of the domestic fowl. Proc. R. Soc. B 166, 34l-357.

Heald, P.J., Diamond, P.S. \& Harrison, D.G. (1967) Examination of the role of poly- $\alpha-L-$ glutamic acid in the maintenance of the fertility of avian spermatozoa in vivo. Br. Poultry Sci. 8, 321-323.

Lake, P.E. (1969) Factors affecting fertility. In The Fertility and Hatchability of the Hen's Egg, pp. 3-29. Eds T. C. Carter \& B. M. Freeman. Oliver \& Boyd, Edinburgh.

Maeda, N. \& Shiga, T. (1985) Inhibition and acceleration of erythrocyte aggregation induced by small macromolecules. Biochim. Biophys. Acta 843, 128-136.

Mantel, N. \& Haentzel, W. (1959) Statistical aspects of the analysis of data from retrospective studies of disease. J. natn. Cancer Inst. 22, 719-748.

Mukherjee, D.C., Agrawal, A.K., Manjunath, R. \& Mukherjee, A.B. (1983) Suppression of epididymal sperm antigenicity in the rabbit by uteroglobin and transglutaminase in vitro. Science, $N Y$ 219, 989-991.

Okamura, F. \& Nishiyama, H. (1978) The passage of spermatozoa through the vitelline membrane of 
the domestic fowl (Gallus gallus). Cell Tiss. Res. 188, 497-508.

Olsen, M.W. \& Neher, B.H. (1948) The site of fertilization in the domestic fowl. J. exp. Zool. 109, 355-366.

Plescia, O.J., Braun, W. \& Palczuk, N.C. (1964) Production of antibodies to denatured deoxyribonucleic acid (DNA). Proc. natn. Acad. Sci. USA 52, 279-285.

Sokal, R.R. \& Rohlf, F.J. (1969) Single classification analysis of variance. In Biometry, pp. 204-252. W. H. Freeman, San Francisco.

Tingari, M.D. \& Lake, P.E. (1973) Ultrastructural studies on the uterovaginal sperm-host glands of the domestic hen, Gallus domesticus. J. Reprod. Fert. 34, 423 431 .

Wassarman, P.M. (1987) The biology and chemistry of fertilization. Science, $N Y$ 235, 553-560.

Williams, R.J.P. (1970) The biochemistry of sodium, potassium, magnesium, and calcium. $Q$. Rev. Chem. Soc. 24, 331-365.

Wishart, G.J. \& Ashizawa, K. (1987) Regulation of the motility of fowl spermatozoa by calcium and cAMP. J. Reprod. Fert. 80, 507-611.

Received 6 February 1989 